\title{
SPECTRAL PROBLEMS FOR ONE MATHEMATICAL MODEL OF HYDRODYNAMICS
}

\author{
I. S. Strepetova ${ }^{1}$, strepetovais@susu.ru, \\ L. M. Fatkullina ${ }^{1}$, fatkullinalm@susu.ru, \\ G. A. Zakirova ${ }^{1}$, zakirovaga@susu.ac.ru. \\ ${ }^{1}$ South Ural State University, Chelyabinsk, Russian Federation.
}

This paper is devoted to the investigation of two spectral problems: the eigenvalue problem and the inverse spectral problem for one mathematical model of hydrodynamics, namely the mathematical model for the evolution of the free filtered-fluid surface. The Galerkin method is chosen as the main method for solving the eigenvalue problem. A theorem on the convergence of Galerkin's method applied to this problem was given. For the given spectral problem the algorithm was developed. A program that allows calculating the eigenvalues of the perturbed operator was produced in Maple. For the inverse spectral problem, the resolvent method was chosen as the main one. For this spectral problem, an algorithm is also developed. A program that allows one to approximately reconstruct the potential from the known spectrum of the perturbed operator was created in Maple. The theoretical results were illustrated by numerical experiments for a model problem. Numerous experiments carried out have shown a high computational efficiency of the developed algorithms.

Keywords: perturbed operator, discrete self-adjoint operator, eigenvalues of the inverse spectral problem, potential, Dzektser equation.

\section{Introduction}

The importance of the spectral theory lies in a wide range of applications in natural science and technology. Spectral problems appear in shell theory, hydrodynamics, quantum mechanics, etc. [1]-[5].

This paper describes spectral problems for equation

$$
(\lambda-\Delta) u_{t}=\alpha \Delta u-\beta \Delta^{2} u+f,
$$

which simulates, as we know, the evolution of the free surface of a liquid filtration [6]. Parameter $\alpha$ is defined by formula

$$
\alpha=\frac{\varepsilon_{\alpha}+k}{k h_{0} a},
$$

where $\alpha$ is the void ratio, $\varepsilon_{\alpha}$ - the power module of the flow through the free surface, $k-$ coefficient of filtration, $h_{0}$ - the pressure on the free surface [6]. Parameters $\lambda$ and $\beta$ are determined by using the following formula

$$
\lambda=\frac{2\left(\varepsilon_{\alpha}+k\right)}{k^{2} H_{0}^{2}}, \quad \beta=\frac{h_{0}}{3 a} .
$$

Research of this problem we can find in the works of many authors. Nonstationary models of the free surface of a liquid filtration were considered [7]. A "quasi-Banach" analogue of the homogeneous Dirichlet problem in a limited area with smooth boundary for a linear Dzektser equation were considered [8]. The existence of of exponential dichotomies of solutions Dzektser evolution equation of the Sobolev type in the quasi-Sobolev spaces can be found in [9]. With regard to the spectral problem, the first attempt initiated in [10]. 


\section{Eigenvalue problem}

Let operators $T, L: \mathfrak{U} \longrightarrow \mathfrak{F}$ are determined by using the following formulas

$$
T=\alpha \Delta-\beta \Delta^{2}, \quad \Delta=\frac{\partial^{2}}{\partial x^{2}}+\frac{\partial^{2}}{\partial y^{2}}, \quad L=\lambda-\Delta,
$$

whereas

$$
\begin{gathered}
\mathfrak{U}=\left\{u \in W_{2}^{k+2}(0, b): u(0)=u(b)\right\}, \\
\mathfrak{F}=\left\{u \in W_{2}^{k}\right\}, k \in 0 \bigcup \mathbb{N}, \\
d o m T=\left\{u \in W_{2}^{k+2}(0, b): u^{\prime \prime}(0)=u^{\prime \prime}(b)=0\right\} \bigcap \mathfrak{U} .
\end{gathered}
$$

Let $P$ - operator of multiplication by a function $p \in C^{2}(0, b)$.

Consider the operator $T+P$. We denote by $\left\{\nu_{n}\right\}_{n=1}^{\infty}=\sigma^{L}(T+P)$, where $\nu_{n}$ numbered in decreasing order of their real parts given algebraic multiplicity.

Using [11] we introduce the $L$-resolvent set of the operator $T$ :

$$
\rho^{L}(T)=\left\{\mu \in \mathbb{C}:(\mu L-T)^{-1} \in \mathcal{L}(F ; U)\right\} ;
$$

$L$-resolvent of the operator $T R_{0}(\mu)=(\mu L-T)^{-1} ; R(\mu)=(\mu L-T-P)^{-1}-L$-resolvent of operator $T+P$.

It is clear that $\mathrm{L}$-eigenvalues of the operator $T$

$$
\mu_{n}=\lambda_{n} \frac{\beta \lambda_{n}-\alpha}{\lambda_{n}-a^{2}}
$$

where $\left\{\lambda_{n}\right\}_{n=1}^{\infty}=\sigma(\Delta)$ - the eigenvalues of the Laplace operator generated by the Dirichlet boundary value problem:

$$
\begin{gathered}
\Delta u=a^{2} u, \quad u(0)=u(b)=0, \\
\lambda_{n}=-n^{2}, n \in N .
\end{gathered}
$$

Consider the direct spectral problem: we know the eigenvalues $T$ and perturbation $p$. We need to find the $L$ - eigenvalues of the perturbed operator $T+P$. For the operator $L$ we have

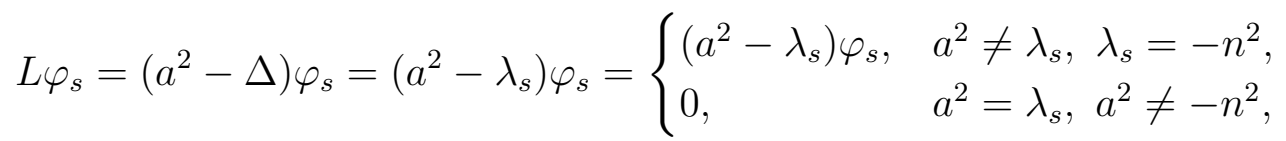

therefore:

$$
\begin{gathered}
R_{0}^{L}(\mu)=\left\{\begin{array}{ll}
\frac{1}{\mu-\mu_{s}}, & a^{2} \neq \lambda_{s}, \\
0, & a^{2}=\lambda_{s},
\end{array} \quad R_{0}^{L}(\mu) \varphi_{s}= \begin{cases}\frac{\varphi_{s}}{\mu-\mu_{s}}, & a^{2} \neq \lambda_{s}, \\
0, & a^{2}=\lambda_{s},\end{cases} \right. \\
R_{0}(\mu)=\left\{\begin{array}{ll}
\frac{1}{\left(\mu-\mu_{s}\right)\left(a^{2}-\lambda_{s}\right)}, & a^{2} \neq \lambda_{s}, \\
\frac{1}{\beta a^{4}-\alpha a^{2}}, & a^{2}=\lambda_{s},
\end{array} \quad R_{0}(\mu) \varphi_{s}= \begin{cases}\frac{\varphi_{s}}{\left(\mu-\mu_{s}\right)\left(a^{2}-\lambda_{s}\right)}, & a^{2} \neq \lambda_{s}, \\
\frac{\varphi_{s}}{\beta a^{4}-\alpha a^{2}}, & a^{2}=\lambda_{s} .\end{cases} \right.
\end{gathered}
$$

Operators $R_{0}(\mu), R_{0}^{L}(\mu), \mu \in \rho(T)$, are nuclear, since the series of eigenvalues of these operators are converge. Let $\gamma_{n}=\left\{\mu \in \mathbb{C}:\left|\mu-\mu_{n}\right|=r_{n}, \quad r_{n}=n \beta-\frac{\beta}{2}\right\}$, where $\beta \in R_{+}$. 


\subsection{Approximate calculation of the eigenvalues}

The relative eigenvalues $\nu_{k}$ of the operator $T+P$ are defined by determining nontrivial solutions of the equation

$$
(T+P) u=\nu L u
$$

that satisfies certain homogeneous boundary conditions.

To find the eigenvalues of the operator $T+P$ we use the method of Galerkin. We introduce the sequence $\left\{H_{n}\right\}_{n=1}^{\infty}$ of finite-dimensional spaces $H_{n} \subseteq H$, which will be full in $H$. Let an orthonormal basis in the space $H_{n}$ is known and it consists of functions $\left\{\varphi_{k}\right\}_{k=1}^{\infty}$. The functions $\varphi_{k}$ must satisfy the boundary conditions of problem. According to the Galerkin method, we seek an approximate solution of the spectral problem (3) in the form of

$$
u_{n}=\sum_{k=1}^{n} a_{k}(n) \varphi_{k}, k \in N .
$$

Operator $T+P$ is a discrete, consequently, its resolvent is completely continuous.

Theorem 1. [12] If the operator $T=A_{0}^{-1} K$ is completely continuous in the $H_{0}$, then the Galerkin process is convergent in the problem of determining eigenvalues.

Using ideas from the works [12], [13] we can prove the next theorem.

Theorem 2. Let operators $T, L: U \rightarrow F$ are defined by formulas

$$
T=\alpha \Delta-\beta \Delta^{2}, \quad \Delta=\frac{d^{2}}{d x^{2}}, \quad L=a^{2}-\Delta,
$$

and besides

$$
\begin{gathered}
U=\left\{u \in W_{2}^{k+2}(0, b): u(x)=0, x \in(0, b)\right\}, \\
F=W_{2}^{k}(0, b), k \in\{0\} \cup \mathbb{N}, u=W_{2}^{k+2}(0, b), \\
d o m T=\left\{u \in W_{2}^{k+2}(0, b): u^{\prime \prime}(0)=u^{\prime \prime}(b)=0\right\} \cap U .
\end{gathered}
$$

Let operator $P$ be the operator of multiplication on the function $p \in C^{2}(0, b)$.

If the system of the coordinate functions $\left\{\varphi_{k}\right\}_{k=1}^{\infty}$ is the basis $H$, the Galerkin method, which is applied to the spectral problem (3) of determining the eigenvalues is convergent. of

If we solve the problem by the Galerkin method, then solution is presented in the form

$$
\varphi(x)=\sum_{k=1}^{n} a_{k} \sin \frac{\pi k x}{b} .
$$

Further we substitute (6) to (3) and construct a discrepancy:

$$
\begin{gathered}
N(x)=L\left[\sum_{k=1}^{n} a_{k} \varphi_{k}(x)\right] \\
N(x)=\alpha u_{x x}-\beta\left(u_{x x}\right)^{2}+P u-\nu a^{2} u+\nu u_{x x} .
\end{gathered}
$$


Next, if we will demand that the discrepancy of the basis functions be orthogonal, we obtain:

$$
\begin{gathered}
\int_{a}^{b} N(x) \varphi_{k}(x) d x=0, \\
\text { so } \quad \int_{a}^{b} a_{k}\left(\alpha u_{x x}-\beta\left(u_{x x}\right)^{2}+P u-\nu a^{2} u+\nu u_{x x}\right) \sin \left(\frac{\pi}{b} k x\right) d x=0 .
\end{gathered}
$$

As a result, when our homogeneous system of equations for the coefficients in the expansion will be solved, we'll have approximate eigenvalues.

\subsection{Computational experiment}

The program in Maple 16 was developed. With the help of this program we can determine the approximate $L$-eigenvalues of the operator $T+P$ using the eigenvalues of the operator $T$ and potential $p$, that we know. Numerical experiments confirm the good computational accuracy. In some experiments, the outrage has been put equal to zero. In this case, was shown high correlation with the results obtained analytically

The results of computational experiments are presented in tables 1 and 2 .

\section{Table 1}

The Numerical Solution of the Problem (3), when $p=0, \alpha=0, \beta=1, a=0, b=\frac{\pi}{4}, a^{2}=2$.

\begin{tabular}{|c||c|}
\hline № & $\nu_{k}$ \\
\hline 1 & -14.22222222 \\
2 & -62.06060606 \\
3 & -142.0273973 \\
4 & -254.0155039 \\
5 & -398.0099502 \\
6 & -574.0069204 \\
7 & -782.0050891 \\
8 & -1022.003899 \\
9 & -1294.003082 \\
10 & -1598.002497 \\
11 & -1934.002064 \\
12 & -2302.001735 \\
13 & -2702.001478 \\
14 & -3134.001275 \\
15 & -3598.001110 \\
16 & -4094.000976 \\
17 & -4622.000865 \\
18 & -5182.000771 \\
19 & -5774.000692 \\
20 & -6398.000625 \\
\hline
\end{tabular}




\section{Table 2}

The Numerical Solution of the Problem (3), for $p=\sin (4 x), \alpha=0, \beta=1, a=0, b=\frac{\pi}{4}, \gamma=1$.

\begin{tabular}{|c||c|}
\hline № & $\nu_{k}$ \\
\hline 1 & -899.0011099 \\
2 & -728.0013699 \\
3 & -575.0017331 \\
4 & -440.0022624 \\
5 & -323.0030769 \\
6 & -224.0044248 \\
7 & -143.0068966 \\
8 & -80.01219512 \\
9 & -35.02702703 \\
10 & -8.100000000 \\
\hline
\end{tabular}

\section{Inverse spectral problem}

We will consider the inverse spectral problem: we know the eigenvalues of the operator $T$ and the perturbation $p$. We need to find the eigenvalues of the perturbed operator $T+P$. One dimensional case was considered in [10]. Further we will consider two-dimensional case, where $\Delta=\frac{\partial^{2}}{\partial x^{2}}+\frac{\partial^{2}}{\partial y^{2}}$.

It can be shown that the equation

$$
p=\alpha_{0}-\alpha(p)
$$

where

$$
\begin{aligned}
& \alpha_{0}=\sqrt{\frac{4}{a b}} \sum_{t=1}^{\infty} \sum_{k=1}^{\nu_{t}}\left(\xi_{t}^{k}-\lambda_{t}\right) \varphi_{t}^{k} \\
& \alpha(p)=(-1)^{N} \sqrt{2^{N} V} \sum_{t=1}^{\infty} \sum_{k=1}^{\nu_{t}} \frac{\alpha_{t}(p)}{\nu_{t}} \varphi_{t}^{k} \\
& \alpha_{t}(p)=\frac{1}{2 \pi i} \int_{\gamma_{r_{t}}} \lambda S p\left[R(\lambda)\left(P R_{0}(\lambda)\right)^{2}\right] d \lambda=\frac{1}{2 \pi i} \int_{\gamma_{r_{t}}} S p\left[\sum_{k=2}^{\infty} R_{0}(\lambda)\left(P R_{0}(\lambda)\right)^{k}\right] d \lambda,
\end{aligned}
$$

has a unique solution $p$.

This solution can be found by using the method of successive approximations

$$
\widetilde{\alpha}(p)=\sum_{t=1}^{\infty} \widetilde{\alpha_{t}}(p) \varphi_{t}, \quad \widetilde{\alpha_{t}}(p)=\frac{1}{2 \pi i} \int_{\gamma_{r_{t}}} \lambda S p\left[R_{0}(\lambda)\left(P R_{0}(\lambda)\right)^{2}\right] d \lambda .
$$

We figure out $\widetilde{\alpha_{t}}\left(\alpha_{0}\right)$.

$$
\begin{gathered}
\widetilde{\alpha}_{t}\left(\alpha_{0}\right)=\frac{1}{2 \pi i} \int_{\gamma_{r_{t}}} \lambda S p\left[R_{0}(\lambda)\left(P_{1} R_{0}(\lambda)\right)^{2}\right] d \lambda= \\
=\sum_{j \neq t} \sum_{k=1}^{\nu_{t}} \frac{\left(\alpha_{0} \varphi_{t}^{k}, \varphi_{j}^{k}\right) \cdot\left(\alpha_{0} \varphi_{j}^{k}, \varphi_{t}^{k}\right)}{\lambda_{t}^{k}-\lambda_{j}^{k}}=\sum_{j \neq t} \sum_{k=1}^{\nu_{t}} \frac{\left(\alpha_{0} \varphi_{t}^{k}, \varphi_{j}^{k}\right)^{2}}{\left(\lambda_{t}^{k}-\lambda_{j}^{k}\right)} .
\end{gathered}
$$


As a result, we obtain a more convenient formula for constructing an algorithm

$$
\widetilde{p}=\alpha_{0}-\sqrt{4 a b}\left(\sum_{j \neq t} \sum_{k=1}^{\nu_{t}} \frac{\left(\alpha_{0} \varphi_{t}, \varphi_{j}\right)^{2}}{\left(\lambda_{t}-\lambda_{j}\right)}\right) \varphi_{t}^{k} .
$$

\subsection{Computational experiment}

Alas, there is no single numerical solution for the problem of determining the potential. We have developed a program in Maple 16. Use this program you can you can determine the approximate potential explicitly, so that the spectrum of the perturbed operator will coincide with this sequence.

We give an example illustrating the work of the program.

$$
(\lambda-\Delta) u_{t}=\alpha \Delta u-\beta \Delta^{2} u+f
$$

Operators $T, L: \mathfrak{U} \longrightarrow \mathfrak{F}$ are determined by formulas

$$
T=\alpha \Delta-\beta \Delta^{2}, \quad \Delta=\frac{\partial^{2}}{\partial x^{2}}+\frac{\partial^{2}}{\partial y^{2}}, \quad L=\lambda-\Delta,
$$

where $\alpha=\frac{8}{10}, \lambda=2.1, \beta=\frac{1}{\pi^{2}}$. Suppose also, $\xi_{n}=\mu_{n}+0.0001, n \leq 10$. There is the potential $p \in L_{2}(0 ; \pi)$ such that for any $n \in \mathbb{N}$

$$
\xi_{n}=\nu_{n}
$$

$\left\{\nu_{m n}\right\}=\sigma^{L}(T+P)$. An approximate potential which we have reconstituted using the program by the first ten members of the sequence $\left\{\xi_{n}\right\}$ shown in Figure.

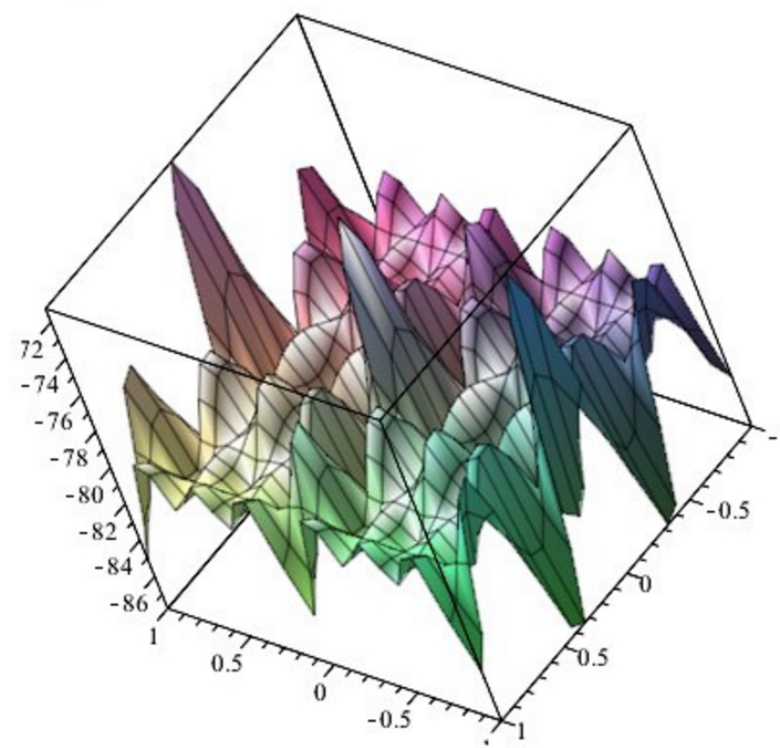

Fig. Reconstituted potential 


\section{References}

1. Torshina O.A. The Eigenvalues of a Perturbed Laplace-Bochner. Science and Modernity. Mathematics, 2013, no. 26-2, pp. 48-52. (in Russian)

2. Dinu T.-L. On a Nonlinear Eigenvalue Problem in Sobolev Spaces with Variable Exponent. Siberian Electronic Mathematical Reports, 2005, vol. 2, pp. 208-217.

3. Rose N.J. On an Eigenvalue Problem Involving Legendre Functions, available at: http://www4.ncsu.edu/ njrose/pdfFiles/Legendre.pdf (accessed on 1 March 2017).

4. Wang X., Ameel T.A., Warrington R.O. Evaluation of the Eigenvalues of the Graetz Problem in Slip-Flow. Int. Comm. Heat Mass Transfer, 1996, vol. 23, no. 4, pp. 563-574.

5. Kac M. Can One Hear the Shape of a Drum? The American Mathematical Monthly, 1966, vol. 73, no. 4, part 2: Papers in Analysis, pp. 1-23. doi: 10.2307/2313748

6. Dzekcer E.S. Generalization of the Equation of Motion of Ground Waters with a Free Surface. Dokl. Akad. Nauk SSSR, 1972, vol. 202, no. 5, pp. 1031-1033. (in Russian)

7. Zamyshlyaeva A.A., Al-Isawi D.K.T. Holomorphic Generate Operator Semigroups and Evolutionary Sobolev Type Equations in Quasi-Sobolev Spaces of Sequences. Bulletin of the South Ural State University. Series: Mathematics. Mechanics. Phisics, 2015, vol. 7, no. 4, pp. 27-36. doi: 10.14529/mmph150404 (in Russian)

8. Sagadeeva M.A., Badoyan A.D. Optimal Control of Solutions to the Multipoint Initial-Final Problem for Nonstationary Relatively Bounded Equations of Sobolev Type. Bulletin of the South Ural State University. Series: Mathematical Modelling, Programming and Computer Software, 2014, vol. 7, no. 3, pp. 128-134. doi: $10.14529 / \mathrm{mmp} 140314$

9. Zamyshlyaeva A.A., Al-Isawi D.K.T. On Some Properties of Solutions to One Class of Evolution Sobolev Type Mathematical Models in Quasi-Sobolev Spaces. Bulletin of the South Ural State University. Series: Mathematical Modelling, Programming and Computer Software, 2015, vol. 8, no. 4, pp. 113-119. doi: 10.14529/mmp150410

10. Zakirova G.A, Kirillov E.V. L-regularized Trace of One of the Perturbed Operator. Bulletin of the Odessa National University. Mathematics and Mechanics, 2013, vol. 18, issue 2(18), pp. 7-13. (in Russian)

11. Sviridyuk G.A., Fedorov V.E. Linear Sobolev Type Equations and Degenerate Semigroups of Operators. Utrecht, Boston, VSP, 2003.

12. Mikhlin S.G. Variational Methods in Mathematical Physics. Translated by Boddington T. Oxford, Pergamon Press, 1964. doi: 10.1017/S0013091500011834

13. Kadchenko S.I., Zakirova G.A. Computation of Eigenvalues of Discrete Lower Semibounded Operators. Applied Mathematical Sciences, 2016, vol. 10, no. 7. pp. 323-329. doi: 10.12988/ams.2016.510625 
Irina S. Strepetova, Bachelor, Department of Equations of Mathematical Physics, South Ural State University (Chelyabinsk, Russian Federation), strepetovais@susu.ru

Lyaysan M. Fatkullina, Bachelor, Department of Equations of Mathematical Physics, South Ural State University (Chelyabinsk, Russian Federation), fatkullinalm@susu.ru

Galiya A. Zakirova, Candidate of Physico-Mathematical Sciences, Docent, Department of Equations of Mathematical Physics, South Ural State University (Chelyabinsk, Russian Federation), zakirova81@mail.ru

Received March 1, 2017

УДК 517.9

DOI: $10.14529 /$ jcem170105

\title{
СПЕКТРАЛЬНЫЕ ЗАДАЧИ ДЛЯ ОДНОЙ МОДЕЛИ ГИДРОДИНАМИКИ
}

\author{
И. С. Стрепетова, Л. М. Фаткуллина, Г. А. Закирова
}

\begin{abstract}
Работа посвящена исследованию двух спектральных задач: задаче на собственные значения и обратной спектральной задаче для одной математической модели гидродинамики, а именно математической модели эволюции свободной поверхности фильтрующейся жидкости. Основным методом решения задачи на собственные значения выбран метод Галеркина. Приведена теорема о сходимости метода Галеркина применительно к данной задаче. Для данной спектральной задачи разработан алгоритм и на его основе в среде Maple написана программа, позволяющая вычислять собственные числа возмущенного оператора. Для обратной спектральной задачи в качестве основного выбран резольвентный метод. Для данной спектральной задачи также разработан алгоритм и на его основе в среде Maple написана программа, позволяющая приближенно восстановить потенциал по известному спектру возмущенного оператора. Теоретические результаты проиллюстрированы с помощью вычислительных экспериментов для модельных задач. Многочисленные проведенные эксперименты показали высокую вычислительную эффективность разработанных алгоритмов.

Ключевые слова: возмущенный оператор, дискретный самосопряженный оператор, собственные значения, уравнение Дзекцера.
\end{abstract}

\section{Литература}

1. Торшина, О.А. Собственные числа возмущенного оператора Лапласа-Бохнера / О.А. Торшина // Наука и современность. Математика. - 2013. - № 26-2. С. 48-52.

2. Dinu, T.-L. On a nonlinear eigenvalue problem in Sobolev spaces with variable exponent / T.-L. Dinu // Сиб. электрон. матем. изв. 2005. - Т. 2. - С. 208-217.

3. Rose, N.J. On an Eigenvalue Problem Involving Legendre Functions / N.J. Rose, доступ: http://www4.ncsu.edu/ njrose/pdfFiles/Legendre.pdf (запрос на 1 марта 2017).

4. Wang, X. Evaluation of the Eigenvalues of the Graetz Problem in Slip-Flow / X. Wang, T.A. Ameel, R.O. Warrington // Int. Comm. Heat Mass Transfer. - 1996. - V. 23, № 4. - P. 563-574. 
5. Kac, M. Can one hear the shape of a drum? / M. Kac // The American Mathematical Monthly. - 1966. - V. 73, № 4, part. 2: Papers in Analysis. - P. 1-23.

6. Дзекцер, Е.С. Обобщенные уравнения движения грунтовых вод со свободной поверхностью / Е.С. Дзекцер // ДАНН СССР. - 1972. - Т. 202, № 5. - С. 1031- 1033.

7. Замышляева, А.А. Голоморфные вырожденные полугруппы операторов и эволюционные уравнения соболевского типа в квазисоболевых пространствах последовательностей / А.А. Замышляева, Д.К.Т. Аль-Исави // Вестн. Южно-Ур. ун-та. Серия «Математика. Механика. Физика». - 2015. - Т. 7, № 4. - С. 27-36.

8. Сагадеева, М.А. Оптимальное управление решениями многоточесной начальноконечной задачи для нестационарных относительно ограниченных уравнений соболевского типа / М.А. Сагадеева, А.Д. Бадоян // Вестн. Юж.-Урал. гос. ун-та. Серия «Математическое моделирование и программирование». - 2014. - Т. 7, № 3. - C. 128-134.

9. Замышляева, А.А. О некоторых свойствах решений одного класса эволюционных математических моделей соболевского типа в квазисоболевых пространствах / А.А. Замышляева, Д.К.Т. Аль-Исави // Вестн. Юж.-Урал. гос. ун-та. Серия «Математическое моделирование и программирование». - 2015. - Т. 8, № 4. C. $113-119$.

10. Закирова, Г.А. Регуляризованный $L$-след одного возмущенного оператора / Г.А. Закирова, Е.В. Кириллов // Вестник Одесского национального университета. Математика и механика. - 2013. - Т. 18, вып. 2(18). - С. 7-13.

11. Sviridyuk, G.A. Linear sobolev type equations and degenerate semigroups of operators / G.A. Sviridyuk, V.E. Fedorov. - Utrecht, Boston: VSP, 2003.

12. Михлин, С.Г. Вариационные методы в математической физике / С.Г. Михлин. М.: Наука, 1970.

13. Kadchenko, S.I. Computation of eigenvalues of discrete lower semibounded operators / S.I. Kadchenko, G.A. Zakirova // Applied Mathematical Sciences. - 2016. - V. 10, № 7 . - P. 323-329.

Стрепетова Ирина Сергеевна, бакалавр, кафедра уравнений математической физики, Южно-Уральский государственный университет (г. Челябинск, Российскал Федераuия),strepetovais@susu.ru

Фаткуллина Ллйсан Маратовна, бакалавр, кафедра уравнений математической физики, Южно-Уральский государственный университет (е. Челябинск, Российская Фeдерачuя),fatkullinalm@susu.ru

Закирова Галия Амрулловна, кандидат физико-математических наук, дочент, кафедра уравнений математической физики, Южно-Уральский государственный университет (г. Челябинск, Российская Федерация), zakirovaga@susu.ru

Поступила в редакиию 1 марта 2017 г. 